\title{
Polaprezinc inhibits liver fibrosis and proliferation in hepatocellular carcinoma
}

\author{
JUN YE $^{1 *}$, ZHENGSEN ZHANG $^{1 *}$, LIANG ZHU ${ }^{2 *}$, MINFANG LU ${ }^{1}$, \\ YAN LI ${ }^{1}$, JINGJING ZHOU ${ }^{1}$, XINLIANG LU ${ }^{1}$ and QIN DU ${ }^{1}$ \\ ${ }^{1}$ Department of Gastroenterology, The Second Affiliated Hospital, Zhejiang University School of \\ Medicine, Zhejiang University; ${ }^{2}$ Department of Laboratory Construction and Management, Hangzhou \\ Normal University School of Medicine, Hangzhou, Zhejiang 310009, P.R. China
}

Received August 25, 2016; Accepted June 2, 2017

DOI: $10.3892 / \mathrm{mmr} .2017 .7262$

\begin{abstract}
Hepatic fibrosis is defined as a pathological process, and activation of hepatic stellate cells (HSCs) is believed to be the key event of liver fibrosis. Additionally, activated HSCs may participate in the formation of the tumor microenvironment. Polaprezinc, a protector of the gastric mucosa, has been recently demonstrated to be an inhibitor of liver fibrosis in a mouse model. Proliferation and colony formation assays were performed to determine the inhibitory effects of polaprezinc on the growth of LX-2 and hepG 2 cells. A migration assay was used to evaluate the change in mobility of LX-2 cells and quantitative polymerase chain reaction was performed to detect the expression levels of key markers of fibrosis. Finally, a gene chip assay for polaprezinc-treated hepG2 cells was performed to evaluate the effect of polaprezinc on the hepG2 gene expression profile. The proliferation assay indicated that polaprezinc may inhibit the LX-2 cell proliferation and the migration assays confirmed the inhibition of mobility. The expression levels of fibrotic markers such as collagen I, fibronectin and $\alpha$-smooth muscle actin were downregulated following polaprezinc treatment. The proliferation activity of polaprezinc-treated hepG2 cells was reduced and the gene chip assay indicated that series of gene expression changes associated with cancer migration, cell skeletal organization and proliferation had occurred. In conclusion, polaprezinc treatment mayinhibit the proliferation of hepatocellular carcinoma cells and reverse liver fibrosis by deactivating HSCs.
\end{abstract}

Correspondence to: Dr Qin Du or Dr Xinliang Lu, Department of Gastroenterology, The Second Affiliated Hospital, Zhejiang University School of Medicine, 88 Jiefang Road, Hangzhou, Zhejiang 310009, P.R. China

E-mail: duq518@163.com

E-mail: xinliang.lu@yahoo.com

*Contributed equally

Key words: polaprezinc, liver fibrosis, hepatic stellate cells, hepatocellular carcinoma
The present findings suggest that polaprezinc provides a novel treatment for patients with gastritis complicated with cirrhosis.

\section{Introduction}

Hepatocellular carcinoma (HCC) is one of the most challenging malignancies worldwide, particularly in China and statistical data revealed that more than half a million individuals succumb to HCC annually worldwide $(1,2)$ and HCC is the third most common cause of cancer-associated death. $\mathrm{HCC}$ is known for its quick progression, high mortality and resistance to majority of chemotherapy types, making palliative care the only available choice (3). Additionally, in most cases patients with HCC are already at the advanced stage by the time of diagnosis. Therefore, it is important to develop therapies that effectively block the initial onset of HCC.

Fibrosis is the process by which fibrogenic cells overproduce large quantities of extracellular matrix (ECM) under specific pathological conditions $(4,5)$, such as hepatitis B virus and hepatitis $\mathrm{C}$ virus infection. It has been previously estimated that up to $90 \%$ of patients with HCC exhibit advanced liver fibrosis or cirrhosis (6-8). The quiescent hepatic stellate cells (HSCs), which reside in the perisinusoidal space are the major producers of ECM in the liver, and production of ECM is believed to be the key event of liver fibrosis (9-11). Once activated by pathological factors such as viral infection, HSCs secrete fibrillar collagens, particularly type I and III, to remodel hepatic tissue, favoring a liver microenvironment that facilitates carcinogenesis by promoting angiogenesis, chronic inflammation and oxidative stress (12-15). Additionally, activated HSCs may participate in the formation of the tumorous environment to promote proliferation, transformation and invasion of HCC (16-18). Collectively, these previous findings suggest that HSCs are an ideal target for HCC treatment.

The development of effective therapies that specifically target HSC remains a challenge. This may due to several factors: There is a HSC-dependent pathway driving hepatocarcinogenesis is elusive, drug-specific multiple transport receptors for drug delivery are lacking in HSCs, and available candidate compounds, including cytokines and short interfering (si)RNAs administered systemically are subject to fast degradation in the plasma due to their short half-lives (19). 
Furthermore, the physiological function of HSCs is essential during liver hemostasis; therefore, suppression of their activation maybe harmful.

Polaprezinc, a zinc complex of L-carnosine, is widely used as a gastric mucosal protector to treat gastric ulcers and a previous study revealed it may inhibit liver fibrosis in mice (20). Although, it was believed that HSCs are involved in polaprezinc-induced reversal of liver fibrosis, more evidence is required to confirm this hypothesis. Cirrhosis is believed to be an irreversible process; however, a previous study indicated that liver fibrosis, which occurs at the early stages of cirrhosis, maybe reversed by inhibiting HSC activation and proliferation (21). The present study aimed to describe the mechanism by which polaprezinc inhibits HSC proliferation and ECM production, along with $\mathrm{HCC}$ formation and progression. These findings may elucidate the mechanism by which polaprezinc blocks HCC development.

\section{Materials and methods}

Cell culture. LX-2 human HSC line, and hepG2 and huh7 human hepatic cancer cell lines were purchased from the cell bank of the China Academy of Medical Science (Shanghai, China) and cultured in RPMI 1640 medium (Gibco; Thermo Fisher Scientific, Inc., Waltham, MA, USA) supplemented with $10 \%$ fetal bovine serum (FBS, Gibco; Thermo Fisher Scientific, Inc.). The cells were maintained at $37^{\circ} \mathrm{C}$ in $5 \% \mathrm{CO}_{2}$.

Cell proliferation assays. LX-2 or hepG2 cells were seeded at a density of $1 \times 10^{3} /$ well in 96 -well plates containing $0.2 \mathrm{ml}$ RPMI 1640 medium with $10 \%$ FBS at 0,8 , or $16 \mu \mathrm{g} / \mathrm{ml}$ respectively. Then $20 \mu \mathrm{l}$ MTS (Promega Corporation, Madison, WI, USA) reagent was added to each well and incubated at $37^{\circ} \mathrm{C}$ for $4 \mathrm{~h}$. The absorbance values were measured at $490 \mathrm{~nm}$ using a microplate reader (Bio-Rad Laboratories, Hercules, CA, USA) and assessed daily for up to 6 days.

Colony forming assay. The proliferation of cells was assessed using a colony formation assay. Approximately 500 cells were seeded per well of a 24-well plate. Following incubation at $37^{\circ} \mathrm{C}$ for 14 days, the cells were washed twice with PBS, fixed with methanol and stained with $0.1 \%$ crystal violet for $15 \mathrm{~min}$ at room temperature. The number of colonies containing more than 300 cells was counted under an inverted microscope (DMI4000; Leica Microsystems GmbH, Wetzlar, Germany).

In vitro migration assay. Transwell insert chambers with an $8-\mu \mathrm{m}$ porous membrane (Corning, Corning, NY, USA) were used for the assay. Cells were washed three times with PBS and $5 \times 10^{4}$ cells were added to the top chamber in serum-free medium. The bottom chamber was filled with RPMI 1640 medium containing 15\% FBS. Cells were incubated for $24 \mathrm{~h}$ at $37^{\circ} \mathrm{C}$ in $5 \% \mathrm{CO}_{2}$. To quantify the migrating cells, cells in the top chamber were removed using a cotton-tipped swab, the migrated cells were fixed in methanol and stained with $0.1 \%$ crystal violet for $15 \mathrm{~min}$ at room temperature. The cells were observed under an inverted microscope (magnification, x100; DMI4000; Leica Microsystems GmbH).

Reverse transcription-quantitative polymerase chain reaction $(R T-q P C R)$. LX-2 cells were treated with 0 or $8 \mu \mathrm{g} / \mathrm{ml}$ polaprezinc (donated by Jilin Broadwell Pharmaceutical Co. Ltd., Jilin, China) for 7 days. Total RNA was extracted from the cultured cells using an RNeasy mini kit (Qiagen GmbH, Hilden, Germany) and treated with RNase-free DNase I (Qiagen $\mathrm{GmbH}$ ) according to the manufacturer's protocol. The RNA was reverse-transcribed into cDNA using Reverse Transcriptase M-MLV (Promega Corporation). The reactions were incubated at $42^{\circ} \mathrm{C}$ for $60 \mathrm{~min}$ and then inactivated at $95^{\circ} \mathrm{C}$ for $10 \mathrm{~min}$. The expression of collagen I, fibronectin and $\alpha$-smooth muscle actin ( $\alpha$-SMA) was measured using SYBR Green PCR Master mix (Thermo Fisher Scientific, Inc.) on the Step One Plus system (Thermo Fisher Scientific, Inc.). The semi-qualification results were analyzed with the $\Delta \Delta \mathrm{Cq}$ methods as formerly defined by Livak and Schmittgen (22). The primers used for qPCR analysis were as follows: Collagen I forward (F) 5'-TTGCCTGTGTCTGAAACGCT-3' and reverse (R) 5'-TGACGAGTGTCCGGTAGTC-3'; fibronectin F 5'-ATTGCCAACCTTTACAGACC-3' and R 5'-GAGTTG TTGGCTCAAAAGC-3'; $\alpha$-SMA (F) 5'-TCCACCTTCCAG CAGATGTGG-3' and R 5'-ACGAGTCAGAGCTTTGGC T-3'; GAPDHF 5'-GGAGCGAGATCCCTCCAAAAT-3' and R 5'-GGCTGTTGTCATACTTCTCATGG-3'. Cycling conditions were $10 \mathrm{~min}$ at $95^{\circ} \mathrm{C}$ for initial denaturation, followed by 40 cycles of $15 \mathrm{sec}$ at $95^{\circ} \mathrm{C}$ for denaturation, $30 \mathrm{sec}$ at $60^{\circ} \mathrm{C}$ for combined annealing and $30 \mathrm{sec}$ at $72^{\circ} \mathrm{C}$ for primer extension. Each sample was run in triplicate and the gene expression levels were normalized to that of GAPDH expression.

Gene chip analysis. After 7 days of treatment with polaprezinc at 0 or $16 \mu \mathrm{g} / \mathrm{ml}$, total RNA from hepG2 cells was extracted using the TRIzol (Invitrogen; Thermo Fisher Scientific, Inc.) method. A NanoDrop ND-1000 spectrophotometer (NanoDrop Technologies; Thermo Fisher Scientific, Inc.) was used to determine RNA concentration. The criteria for absorbance ratios was established as $\mathrm{A}_{260} / \mathrm{A}_{280} \mathrm{Z} 1.8$ and $\mathrm{A}_{260} / \mathrm{A}_{230} \mathrm{Z1.5}$. The criteria for the RNA integrity number value was set at 46 . Genomic DNA contamination was evaluated by gel electrophoresis. Microarray analysis was performed using OneArray (array version HOA 7.1), which contains 31,741 mRNA probes, detecting 20,672 genes in the human genome (data may be downloaded from www.ncbi.nlm.nih.gov; GEO no. GSE101305).

Statistical analysis. Data are presented as the mean \pm standard error. One-way analysis of variance followed by Fisher's least significant difference test was used for multiple group comparisons; otherwise, data were analyzed using a two-tailed unpaired Student's t-test. $\mathrm{P}<0.05$ was considered to indicate a statistically significant difference.

\section{Results}

Polaprezinc suppresses hepatic stellate cell growth in vitro. Proliferation experiments were performed on the LX-2, huh7 and hepG2 cell lines (Fig. 1). The in vitro experiments revealed that the number of proliferating LX-2 cells treated with 8 or $16 \mu \mathrm{g} / \mathrm{ml}$ polaprezinc after 3 days was significantly lower than that of cells treated with $0 \mu \mathrm{g} / \mathrm{ml}$ polaprezinc (Fig. 1A; Day 3, $\mathrm{P}=0.0025$; Day 4, $\mathrm{P}<0.0001$; Day 5, $\mathrm{P}<0.0001$; Day $6, \mathrm{P}=0.0002 ; 0$ vs. $8 \mu \mathrm{g} / \mathrm{ml}$ ), while there was no significant difference between 8 and $16 \mu \mathrm{g} / \mathrm{ml}$ polaprezinc. These results 
A

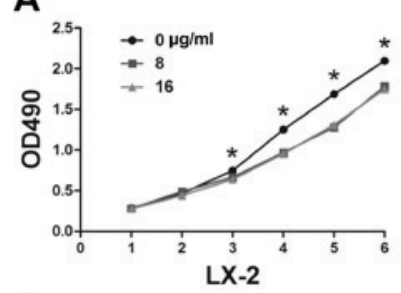

C

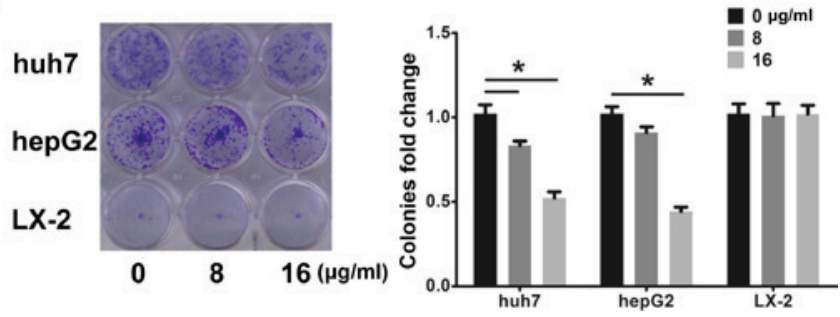

Figure 1. Growth and colony formation assays in LX-2 human hepatic stellate cells, and hepG2 and huh7 human hepatic cancer cell lines. Cell proliferation of (A) LX-2 and (B) hepG2 cells exposed to polaprezinc and controls. ${ }^{*} \mathrm{P}<0.05$ vs. $0 \mu \mathrm{g} / \mathrm{ml}$. (C) Colony formation assays of hepatic cancer cells and hepatic stellate cells. ${ }^{*} \mathrm{P}<0.05$.

indicate that therapeutic concentrations of polaprezinc may inhibit proliferation of HSCs. The proliferation inhibition in human hepatic stellate cells could not be compared in plate cloning experiment as LX-2 could not form cell clones ( 0 vs. $8 \mu \mathrm{g} / \mathrm{ml}, \mathrm{P}=0.881 ; 0$ vs. $16 \mu \mathrm{g} / \mathrm{ml}, \mathrm{P}=0.9702)$.

Polaprezinc suppresses hepatocellular carcinoma cell growth in vitro. In vitro cell proliferation experiments indicated that the number of hepG2 cells was significantly reduced following treatment with 8 or $16 \mu \mathrm{g} / \mathrm{ml}$ polaprezinc, compared with $0 \mu \mathrm{g} / \mathrm{ml}$ polaprezinc, after 5 days (Fig. 1B; Day 5, $\mathrm{P}=0.0033$; Day $6, \mathrm{P}<0.0001 ; 0$ vs. $8 \mu \mathrm{g} / \mathrm{ml}$ ), whereas there was no significant difference between the 8 and $16 \mu \mathrm{g} / \mathrm{ml}$ polaprezinc treatments. Moreover, polaprezinc significantly inhibit proliferation of human hepatoma cells huh7 $(0 \mathrm{vs} .8 \mu \mathrm{g} / \mathrm{ml}$, $\mathrm{P}=0.0131 ; 0$ vs. $16 \mu \mathrm{g} / \mathrm{ml}, \mathrm{P}<0.0001)$ and hepG2 (0 vs. $8 \mu \mathrm{g} / \mathrm{ml}$, $\mathrm{P}=0.0527 ; 0$ vs. $16 \mu \mathrm{g} / \mathrm{ml}, \mathrm{P}<0.0001)$ in plate cloning experiments. The aforementioned findings revealed that therapeutic concentrations of polaprezinc may inhibit the proliferation of human hepatocellular carcinoma cells (Fig. 1C).

Polaprezinc inhibits migration of hepatic stellate cells in vitro. The viability of HSCs is associated with the progression of liver cirrhosis. The Transwell assay was used to analyze cell viability as this is an essential prerequisite for cell migration. The results indicated that the migratory ability of LX-2 cells was significantly reduced following treatment with $8 \mu \mathrm{g} / \mathrm{ml}$ polaprezinc, suggesting that polaprezinc may improve liver cirrhosis by inhibiting HSC viability (Fig. 2; $\mathrm{P}=0.0082$ ).

Polaprezinc inhibits fibrotic marker levels in hepatic stellate cells. Liver fibrotic markers are important serological indicators for monitoring cirrhosis progression. The present study demonstrated that the mRNA levels of hepatic fibrotic indicators including collagen I, fibronectin and $\alpha$-SMA were significantly reduced in LX-2 cells treated with $8 \mu \mathrm{g} / \mathrm{ml}$
A

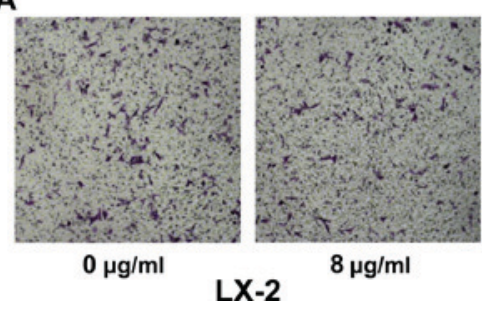

B

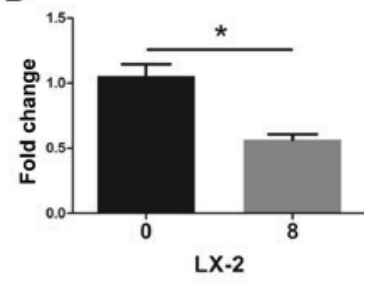

Figure 2. Effects of polaprezinc treatment on LX-2 human hepatic stellate cell migration. (A) Representative photographs of cell migration assays of LX-2 cells treated with polaprezinc, compared with controls. (B) Statistical analysis of cell migration assays. ${ }^{*} \mathrm{P}<0.05$.

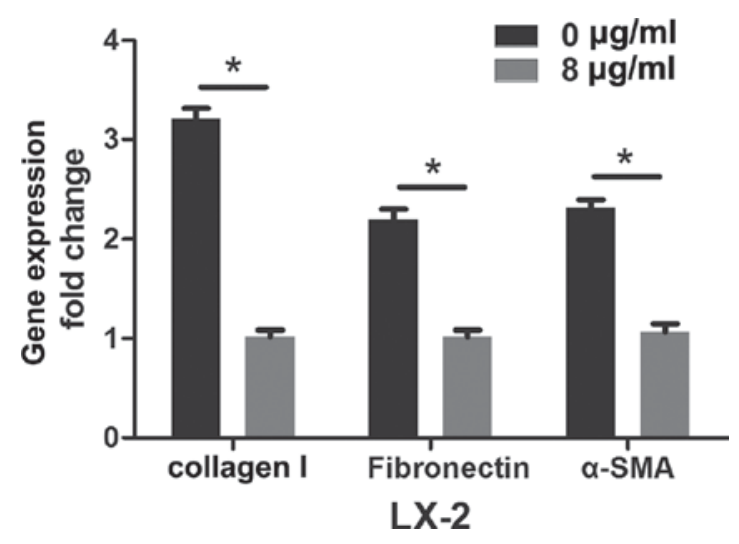

Figure 3. Effects of polaprezinc on the mRNA expression of fibrotic markers including collagen I, fibronectin and $\alpha$-SMA were analyzed using reverse transcription-quantitative polymerase chain reaction. $\alpha$-SMA, asmooth muscle actin. ${ }^{*} \mathrm{P}<0.05$.

polaprezinc compared with those treated with $0 \mu \mathrm{g} / \mathrm{ml}$ (Fig. 3; collagen I P $<0.0001$; fibronectin $\mathrm{P}=0.0008$; $\alpha$-SMA P $=0.0004)$.

Gene ontology enrichment analysis based on function. Treatment with $16 \mu \mathrm{g} / \mathrm{ml}$ polaprezinc inhibited the growth of liver cancer cells. HepG2 cells were treated with 0 or $16 \mu \mathrm{g} / \mathrm{ml}$ polaprezinc for 7 days and RNA was extracted by the TRIzol method. Based on the gene ontology (GO) database (david. ncifcrf.gov), differentially expressed genes (DEGs) were identified in cells treated with $16 \mathrm{vs} .0 \mu \mathrm{g} / \mathrm{ml}$ polaprezinc and 202 DEGs were found to be altered $>1.5$-fold. According to biological process, the DEGs were primarily associated with extracellular stimuli for the regulation of cell growth, chemotaxis, behavior and cell surface receptor-linked signal transduction, such as the G-protein-coupled receptor signaling pathway. Cellular component classification revealed that the DEGs were associated mainly with the cytoskeleton, integral to membranes. Biological functional classification indicated that the DEGs were associated primarily with cytoskeletal protein binding, including actin binding, such as tropomyosin binding (Fig. 4).

\section{Discussion}

Various methods have been considered to treat liver fibrosis, most of which may inhibit myofibroblast activation by targeting the transforming growth factor- $\beta$ (TGF- $\beta$ ) signaling 
A

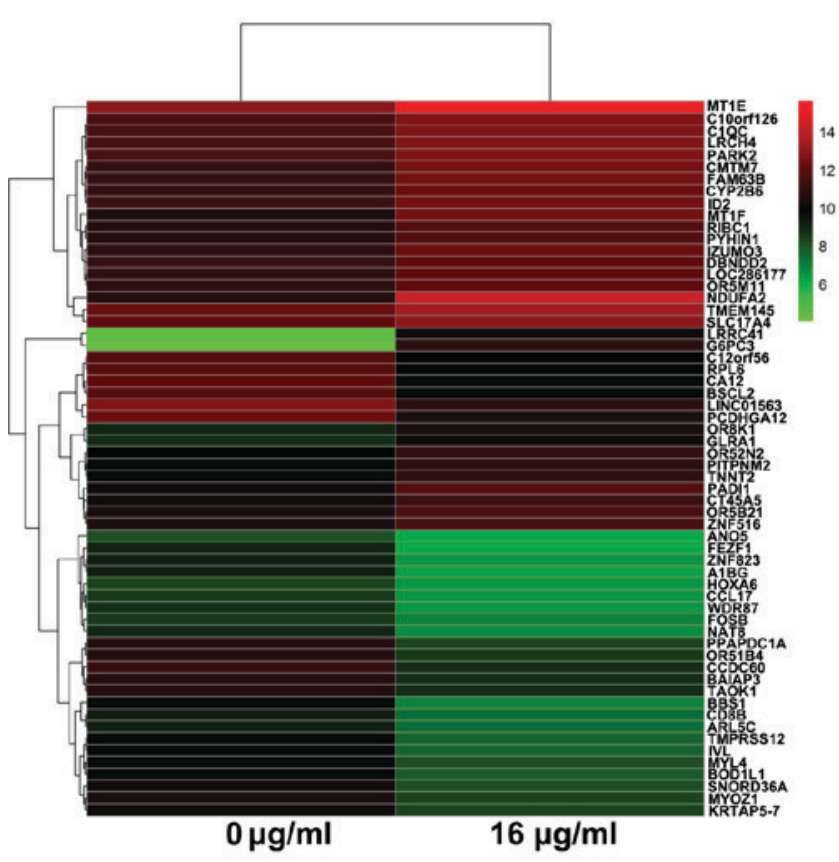

B

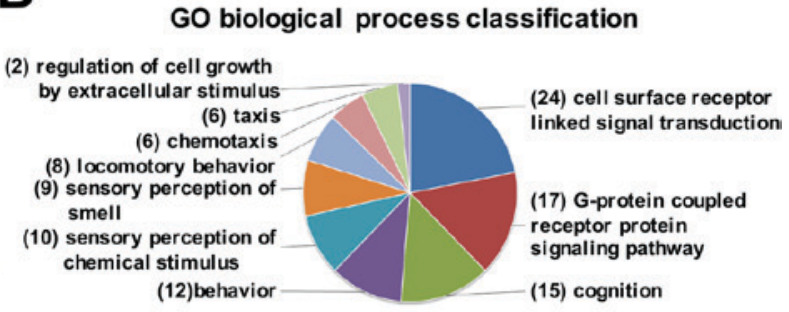

GO cellular component classification

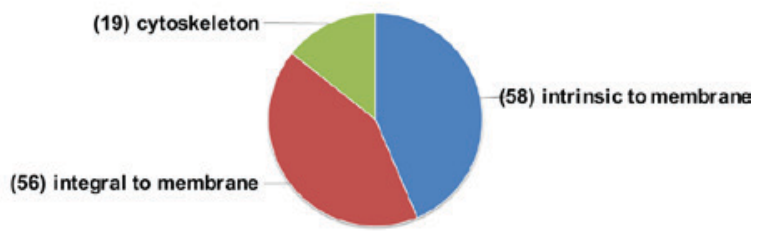

GO biological functional classification

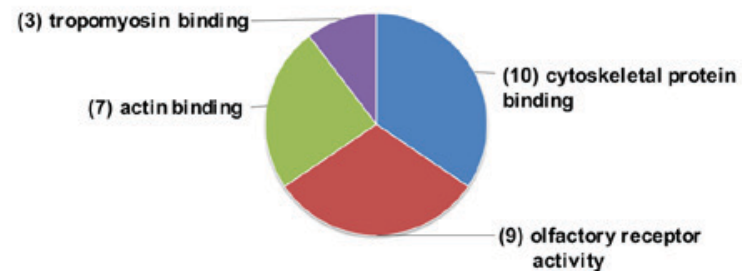

Figure 4. (A) Hierarchical clustering of differentially expressed genes and (B) GO enrichment analysis of the top differentially expressed mRNAs. GO, gene ontology.

axis, which is one of the most potent stimuli of extracellular matrix synthesis. Fan et al (23) and Ling et al (24) demonstrated that TGF- $\beta$ neutralization in animal models attenuated liver fibrosis and prevented development of cholangiocarcinoma $(23,24)$. Additionally, the anti-human-TGF- $\beta$ monoclonal antibody fresolimumab has been developed and is under clinical investigation for several malignancies $(25,26)$. The TGF- $\beta$ Ser/Thr kinase receptor (TGF $\beta$ R1) is necessary for TGF- $\beta$ signal transduction and the TGF $\beta$ R1 inhibitor GW6604 (2-phenyl-4-(3-pyridin-2-yl-1H-pyrazol-4-yl)-pyridine) has been previously reported to be effective in ECM deposition and improving liver function in mice (27). Furthermore, the TGF- $\beta$-regulated gene connective tissue growth factor (CTGF) is recognized as a specific promoter of fibrosis and small interfering RNA-mediated CTGF knockdown blocked C-C motif chemokine ligand 4-induced liver fibrosis (28). However, TGF- $\beta$-inhibition may also induce some unwanted side effects, including sustained inflammation and an increased risk of carcinogenesis. The present study introduced a novel therapy to reverse liver fibrosis, polaprezinc, a drug that is widely used to treat gastric disease with acceptable toxicity and that is more economical compared with newly developed molecular drugs targeting the TGF- $\beta$ pathway.

Previous studies indicate that liver fibrosis maybe reversed or even eliminated by immediate therapies, including hepatocyte protection and regeneration, as well as deactivation of HSCs, which are the primary source of fibrosis in the liver (29-32). Therefore, it is possible to control liver fibrosis by targeting HSCs. Fibronectin, collagen I, and $\alpha$-SMA are associated with HSC activation. $\alpha$-SMA production may induce conversion of HSCs into myofibroblasts and is a hallmark of HSC activation (33), accompanied by deposition of ECM, which contains type I collagen and fibronectin $(34,35)$.

Polaprezinc is widely used as a protector of the gastric mucosa and previous studies have confirmed that it may inhibit liver fibrosis in mice $(36,37)$. The present study aimed to identify the ability of polaprezinc to deactivate HSCs in vitro; therefore, LX-2 cells were treated, leading to inhibition of both cell proliferation and migration by polaprezinc, as presented in Figs. 1A and 2. The underlying molecular mechanism was subsequently investigated. mRNA was extracted from polaprezinc-treated LX-2 cells, and the expression levels of collagen I, fibronectin, and $\alpha$-SMA were analyzed using qPCR. In line with Figs. 1A and 2, the findings indicated that the expression of these fibrosis-associated markers were reduced to at least $30-50 \%$ following polaprezinc treatment (Fig. 3). The present study confirmed that polaprezinc may deactivate HSCs by inhibiting both cell behavior transitions and essential gene production. Due to its critical role in HCC progression, polaprezinc may be valuable to be developed as an adjuvant for additional anti-HCC therapies and damage the essential microenvironment for HCC.

Cirrhosis is a pathological event involved in the development of HCC $(38,39)$. It was believed that HCC progression may be a consequence of the interaction between activated HSC, potential HCC and the other cell components of the peritumoral microenvironment (17), which promote the invasiveness of the HCC cells (40). Coulouarn et al (41) simulated the direct interaction between the HSC and the HCC by 
co-culturing the LX2 cells with HepaRG and a 292-gene signature was determined (41). In the present study, polaprezinc treatment inhibited proliferation of the hep G2HCC cell line in an in vitro clone formation assay. mRNA from treated hepG2 cells was prepared for further digital gene expression analysis based on the GO database. The analyzed results indicated that as many as 202 genes exhibited a 1.5-fold change compared with the control group. These genes were sorted into the following categories: Regulation of cell proliferation, cytoskeleton formation and cell mobility. For example, metallothionein $1 \mathrm{E}$ overexpression may increase the migration of cancer cells and lead to metastasis, leucine rich repeat containing 4 hypermethylation was directly associated with $\mathrm{HCC}$ genesis and C-C motif chemokine ligand 17 is believed to promote HCC proliferation and may be perceived as a prognostic marker (42-44).

In conclusion, the present study introduced a novel therapy that may reverse liver fibrosis an inhibit HCC progression by blocking HSC and HCC proliferation, and HSC migration, together with downregulation of fibrosis-associated key molecules, such as collagen I, fibronectin and $\alpha$-SMA. The present study may lead to the clinical use of polaprezinc or its derivatives as novel anti-HCC therapy.

\section{Acknowledgements}

The present study was supported by grants from Zhejiang Provincial Natural Science Foundation of China (grant nos. LY16H160030 and Q12H160052). Many thanks to Jilin Broadwell Pharmaceutical Co., Ltd., (Jilin, China) for providing the active pharmaceutical ingredient of polaprezinc.

\section{References}

1. El-Serag HB and Rudolph KL: Hepatocellular carcinoma: Epidemiology and molecular carcinogenesis. Gastroenterology 132: 2557-2576, 2007.

2. Tang ZY: Hepatocellular carcinoma-cause, treatment and metastasis. World J Gastroenterol 7: 445-454, 2001.

3. Thomas MB, O'Beirne JP, Furuse J, Chan AT, Abou-Alfa G and Johnson P: Systemic therapy for hepatocellular carcinoma: Cytotoxic chemotherapy, targeted therapy and immunotherapy. Ann Surg Oncol 15: 1008-1014, 2008.

4. Friedman SL: Hepatic stellate cells: Protean, multifunctional, and enigmatic cells of the liver. Physiol Rev 88: 125-172, 2008.

5. Henderson NC and Iredale JP: Liver fibrosis: Cellular mechanisms of progression and resolution. Clin Sci (Lond) 112: 265-280, 2007

6. Chiesa R, Donato F, Tagger A, Favret M, Ribero ML, Nardi G, Gelatti U, Bucella E, Tomasi E, Portolani N, et al: Etiology of hepatocellular carcinoma in Italian patients with and without cirrhosis. Cancer Epidemiol Biomarkers Prev 9: 213-216, 2000.

7. Budhu A and Wang XW: The role of cytokines in hepatocellular carcinoma. J Leukoc Biol 80: 1197-1213, 2006.

8. Sangiovanni A, Del Ninno E, Fasani P, De Fazio C, Ronchi G, Romeo R, Morabito A, De Franchis R and Colombo M: Increased survival of cirrhotic patients with a hepatocellular carcinoma detected during surveillance. Gastroenterology 126: 1005-1014, 2004.

9. Tacke F and Weiskirchen R: Update on hepatic stellate cells: Pathogenic role in liver fibrosis and novel isolation techniques. Expert Rev Gastroenterol Hepatol 6: 67-80, 2012.

10. Coulouarn C and Clément B: Stellate cells and the development of liver cancer: Therapeutic potential of targeting the stroma. J Hepatol 60: 1306-1309, 2014.

11. Mederacke I, Hsu CC, Troeger JS, Huebener P, Mu X, Dapito DH, Pradere JP and Schwabe RF: Fate tracing reveals hepatic stellate cells as dominant contributors to liver fibrosis independent of its aetiology. Nat Commun 4: 2823, 2013.
12. Huang G and Brigstock DR: Regulation of hepatic stellate cells by connective tissue growth factor. Front Biosci (Landmark Ed) 17: 2495-2507, 2012.

13. Huang $\mathrm{G}$ and Brigstock DR: Integrin expression and function in the response of primary culture hepatic stellate cells to connective tissue growth factor (CCN2). J Cell Mol Med 15: 1087-1095, 2011.

14. Pintilie DG, Shupe TD, Oh SH, Salganik SV, Darwiche H and Petersen BE: Hepatic stellate cells' involvement in progenitor-mediated liver regeneration. Lab Invest 90: 1199-1208, 2010.

15. Hernandez-Gea V, Toffanin S, Friedman SL and Llovet JM: Role of the microenvironment in the pathogenesis and treatment of hepatocellular carcinoma. Gastroenterology 144: 512-527, 2013.

16. Zhao W, Zhang L, Yin Z, Su W, Ren G, Zhou C, You J, Fan J and Wang X: Activated hepatic stellate cells promote hepatocellular carcinoma development in immunocompetent mice. Int J Cancer 129: 2651-2661, 2011

17. Ju MJ, Qiu SJ, Fan J, Xiao YS, Gao Q, Zhou J, Li YW and Tang ZY: Peritumoral activated hepatic stellate cells predict poor clinical outcome in hepatocellular carcinoma after curative resection. Am J Clin Pathol 131: 498-510, 2009.

18. Amann T, Bataille F, Spruss T, Mühlbauer M, Gäbele E, Schölmerich J, Kiefer P, Bosserhoff AK and Hellerbrand C: Activated hepatic stellate cells promote tumorigenicity of hepatocellular carcinoma. Cancer Sci 100: 646-653, 2009.

19. Poelstra K, Beljaars L and Melgert BN: Cell-specific delivery of biologicals: Problems, pitfalls and possibilities of antifibrotic compounds in the liver. Drug Discov Today 18: 1237-1242, 2013.

20. Doi H, Fujiwara M, Suzuki H, Niwa Y, Nakayama M, Shikata T, Odawara S, Takada Y, Kimura T, Kamikonya N and Hirota S: Polaprezinc reduces the severity of radiation-induced mucositis in head and neck cancer patients. Mol Clin Oncol 3: 381-386, 2015.

21. Sohrabpour AA, Mohamadnejad M and Malekzadeh R: Review article: The reversibility of cirrhosis. Aliment Pharmacol Ther 36: 824-832, 2012.

22. Livak KJ and Schmittgen TD: Analysis of relative gene expression data using real-time quantitative PCR and the 2(-Delta Delta C(T)) method. Methods 25: 402-408, 2001.

23. Fan X, Zhang Q, Li S, Lv Y, Su H, Jiang H and Hao Z: Attenuation of CCl4-induced hepatic fibrosis in mice by vaccinating against TGF- $\beta 1$. PLoS One 8: e82190, 2013.

24. Ling H, Roux E, Hempel D, Tao J, Smith M, Lonning S, Zuk A, Arbeeny $\mathrm{C}$ and Ledbetter S: Transforming growth factor $\beta$ neutralization ameliorates pre-existing hepatic fibrosis and reduces cholangiocarcinoma in thioacetamide-treated rats. PLoS One 8: e54499, 2013.

25. Trachtman H, Fervenza FC, Gipson DS, Heering P, Jayne DR, Peters H, Rota S, Remuzzi G, Rump LC, Sellin LK, et al: A phase 1 , single-dose study of fresolimumab, an anti-TGF- $\beta$ antibody, in treatment-resistant primary focal segmental glomerulosclerosis. Kidney Int 79: 1236-1243, 2011.

26. Morris JC, Tan AR, Olencki TE, Shapiro GI, Dezube BJ, Reiss M, Hsu FJ, Berzofsky JA and Lawrence DP: Phase I study of GC1008 (fresolimumab): A human anti-transforming growth factor-beta (TGF $\beta$ ) monoclonal antibody in patients with advanced malignant melanoma or renal cell carcinoma. PLoS One 9: e90353, 2014.

27. de Gouville AC, Boullay V, Krysa G, Pilot J, Brusq JM, Loriolle F, Gauthier JM, Papworth SA, Laroze A, Gellibert F and Huet S: Inhibition of TGF-beta signaling by an ALK5 inhibitor protects rats from dimethylnitrosamine-induced liver fibrosis. $\mathrm{Br}$ J Pharmacol 145: 166-177, 2005.

28. Hao C, Xie Y, Peng M, Ma L, Zhou Y, Zhang Y, Kang W, Wang J, Bai X, Wang P and Jia Z: Inhibition of connective tissue growth factor suppresses hepatic stellate cell activation in vitro and prevents liver fibrosis in vivo. Clin Exp Med 14: 141-150, 2014.

29. Sobrevals L, Rodriguez C, Romero-Trevejo JL, Gondi G, Monreal I, Pañeda A, Juanarena N, Arcelus S, Razquin N, Guembe L, et al: Insulin-like growth factor I gene transfer to cirrhotic liver induces fibrolysis and reduces fibrogenesis leading to cirrhosis reversion in rats. Hepatology 51: 912-921, 2010.

30. Chang TT, Liaw YF, Wu SS, Schiff E, Han KH, Lai CL, Safadi R, Lee SS, Halota W, Goodman Z, et al: Long-term entecavir therapy results in the reversal of fibrosis/cirrhosis and continued histological improvement in patients with chronic hepatitis B. Hepatology 52: 886-893, 2010.

31. Troeger JS, Mederacke I, Gwak GY, Dapito DH, Mu X, Hsu CC, Pradere JP, Friedman RA and Schwabe RF: Deactivation of hepatic stellate cells during liver fibrosis resolution in mice. Gastroenterology 143: 1073-1083.e22, 2012. 
32. Henderson NC, Arnold TD, Katamura Y, Giacomini MM, Rodriguez JD, McCarty JH, Pellicoro A, Raschperger E, Betsholtz C, Ruminski PG, et al: Targeting of av integrin identifies a core molecular pathway that regulates fibrosis in several organs. Nat Med 19: 1617-1624, 2013.

33. Iredale JP: Models of liver fibrosis: Exploring the dynamic nature of inflammation and repair in a solid organ. J Clin Invest 117: 539-548, 2007

34. Aycock RS and Seyer JM: Collagens of normal and cirrhotic human liver. Connect Tissue Res 23: 19-31, 1989.

35. Altrock E, Sens C, Wuerfel C, Vasel M, Kawelke N, Dooley S, Sottile J and Nakchbandi IA: Inhibition of fibronectin deposition improves experimental liver fibrosis. J Hepatol 62: 625-633, 2015.

36. Kono T, Asama T, Chisato N, Ebisawa Y, Okayama T, Imai K, Karasaki H, Furukawa $\mathrm{H}$ and Yoneda M: Polaprezinc prevents ongoing thioacetamide-induced liver fibrosis in rats. Life Sci 90: $122-130,2012$.

37. Sugino H, Kumagai N, Watanabe S, Toda K, Takeuchi O, Tsunematsu S, Morinaga S and Tsuchimoto K: Polaprezinc attenuates liver fibrosis in a mouse model of non-alcoholic steatohepatitis. J Gastroenterol Hepatol 23: 1909-1916, 2008.

38. Gao B and Bataller R: Alcoholic liver disease: Pathogenesis and new therapeutic targets. Gastroenterology 141: 1572-1585, 2011.

39. Koh WP, Wang R, Jin A, Yu MC and Yuan JM: Diabetes mellitus and risk of hepatocellular carcinoma: Findings from the Singapore Chinese Health Study. Br J Cancer 108: 1182-1188, 2013.
40. Okabe H, Beppu T, Hayashi H, Horino K, Masuda T, Komori H, Ishikawa S, Watanabe M, Takamori H, Iyama $\mathrm{K}$ and Baba $\mathrm{H}$ : Hepatic stellate cells may relate to progression of intrahepatic cholangiocarcinoma. Ann Surg Oncol 16: 2555-2564, 2009.

41. Coulouarn C, Corlu A, Glaise D, Guénon I, Thorgeirsson SS and Clement B: Hepatocyte-stellate cell cross-talk in the liver engenders a permissive inflammatory microenvironment that drives progression in hepatocellular carcinoma. Cancer Res 72: 2533-2542, 2012

42. Wu Y, Siadaty MS, Berens ME, Hampton GM and Theodorescu D: Overlapping gene expression profiles of cell migration and tumor invasion in human bladder cancer identify metallothionein $1 \mathrm{E}$ and nicotinamide $\mathrm{N}$-methyltransferase as novel regulators of cell migration. Oncogene 27: 6679-6689, 2008.

43. Gao F, Liang H, Lu H, Wang J, Xia M, Yuan Z, Yao Y, Wang T, Tan X, Laurence A, et al: Global analysis of DNA methylation in hepatocellular carcinoma by a liquid hybridization capture-based bisulfite sequencing approach. Clin Epigenetics 7: 86, 2015.

44. Zhou SL, Zhou ZJ, Hu ZQ, Huang XW, Wang Z, Chen EB, Fan J, Cao Y, Dai Z and Zhou J: Tumor-associated neutrophils recruit macrophages and T-Regulatory cells to promote progression of hepatocellular carcinoma and resistance to sorafenib. Gastroenterology 150: 1646-1658.e17, 2016. 